\title{
A Propósito da Simplificação Burocrática
}

$C^{1}$

om o Decreto $n^{\circ} 39.510$, de 4 de julho de 1956 , que criou a Comissão de Simplificação Burocrática (C.O.S.B.) e Subcomissões, nos Ministérios, ficou lançada a Campanha de Simplificação.

A C.O.S.B. e as Subcomissões, em articulação com o D.A.S.P., são os órgãos especiais incumbidos da missão de levar avante o programa de recuperação dos serviços públicos federais, no que serão assessorados pelas Seções de Organização, dos Departamentos de Administração.

Graças à circunstância de as Seções de Organização estarem tècnicamente ligadas ao D.A.S.P., através do Serviço de Organização e Métodos, a C.O.S.B., as Subcomissões, as Seções de Organização e o Serviço de Organização e Métodos deverão funcionar articuladamente, constituindo um verdadeiro sistema, a exemplo dos já existentes nos setores de pessoal, material e orçamento.

Logo nos primeiros momentos ficou evidenciado que o êxito da Campanha dependia da Compreensão, boa vontade e habilitação dos chefes imediatos e, também, da atuação de uma equipe de analistas, experimentados em simplificação do trabalho. Evidenciouse que êsse seria o primeiro problema a enfrentar, pois nada ainda havia sido feito nesse sentido, entre os órgãos da Administração Pública centralizada.

Por isso, a providência básica e imediata seria a de instituir cursos intensivos, para chefes e para formação de analistas, sem o que não seria possivel efetivar : Campanha.

Dessa missão incumbiu-se o Serviço de Organização e Métodos, que planejou a realização de cursos especializados, destinados a servidores das Seções de Organização, das Subcomissões e a chefes de seção. Assim, ao mesmo tempo em que se procederia ao lançamento da idéia, procurando favorecer sua aceitação, prepararse-ia o pessoal necessário à sua efetivação. 
Vale destacar que o que mais se espera da Campanha, e que constitui, por assim dizer, sua finalidade, não é sòmente o incremento da produtividade de suas unidades administrativas e técnicás, e, òbviamente, a redução do custo de sua manutenção. Êsses resultados práticos e outros, tão ardentemente desejados e que serão certamente perseguidos pelos órgãos responsáveis, não devem ser considerados cơmo objetivos. São simples meios.

E' que sua finalidade se situa em plano mais elevado. Insere suas raízes na própria finalidade do Estado, cujos instrumentos de ação encontram-se no seu aparelhamento administrativo e técnico.

Portanto, a Campanha não deve ser considerada corno um movimento inspirado, apenas, em resultados econômicos, com a preocupação de obter maior e melhor aproveitamento de pessoal, material, recursos, espaço e energias, com o que se dão por bem satisfeitas as organizações privadas. No campo das instituições públicas, o aspecto econômico é superado pelos reflexos sociais que a Campanha possa ocasionar.

Do ponto de vista fenomenológico, a Campanha surge aos olhos dos estudiosos como um evento inevitável e previsível. E' a marcha natural de um organismo que se viu forçado a crescer, que foi compelido por condições e circunstâncias múltiplas a expandir-se e a intervir, em escala sempre crescente, e que, para isso, multiplicou os quadros de seus servidores e ampliou a área de sua influência direta.

Êsse crescimento insopitável, dotado de um dinamismo incoercível, e que simboliza a admirável vitalidade de nossas instituições públicas, veio, porém, exibir um quadro de defeitos, até então imperceptiveis: excessos de centralização, descentralizações inadequadas. falta de delegação de competência, ausência de rotinas simplificadas, duplicidade de funções, mau aproveitamento dos recursos disponiveis, etc.

Tais anomalias, inevitáveis, assinaladas em qualquer serviço público civil que se agiganta, irão constituir a preocupação dominante do Sistema Organizador, o qual, bastante prejudicado pela extinção da antiga Divisão de Organização e Coordenação do D.A.S.P., subseqüente à das Comissões de Eficiência ministeriais, vem a custo reconstituindo-se, desde a criação de uma Seção de Organização no Departamento de Administração do Ministério da Justiça - medida depois generalizada aos D. A. dos outros 
Ministérios civis - até o recente refôrço que lhe é acrescentado pela instituição da C.O.S.B. e respectivas Subcomissões, especialmente criadas para dar ênfase à Campanha de Simplificação Burocrática. .

Encarada do ponto de vista cronológico, a providência do Govêrno suscita divergências. Para uns, a Campanha veio ceđo demais, pois não se fêz anteceder de uma intensa, sistemática e permanente fase de preparação psicológica. Para outros, surgiu tarcle, porque não se aproveitou do entusiasmo e do idealismo contagiantes que se seguiram aos primeiros momentos da implantação do sistema do mérito no Brasil, através da Lei n. ${ }^{\circ} 284$, de 28 de outubro de 1936.

De um ou de outro modo, a Campanha terá que prosseguir. A Administração dispõe de um Sistema, a que caberá elaborar um plano e programa de trabalho e promover sua execução, scbretudo norque os resultados da presente Campanha terão que ser consolidados por uma atitude permanente de análise e simplificação, mormente por parte das chefias executivas, dos métodos e normas de trabalho empregados em tôdas as ramificações do serviço burocrático civil.

Justamente por entender que, dentre as funções inerentes à atividade de chefia, a de organizar se situa em plano só igualado pela de treinamento, é que a Revista do Serviço Público, sempre atenta às iniciativas dignas de registro, vem divulgando, desde o número de abril e no presente conclui, o "Manual de Simplificação do Trabalho" que o Instituto de Aposentadoria e Pensões dos Industriários, muito acertadamente, fêz organizar para orientar os respectivos chefes, na aplicação das técnicas de análise e simplificação do trabalho.

Na oportunidade, portanto, do lançamento de tão meritória Campanha, a Revista do Serviço Público chama a atenção de seus leitores, e principalmente a dos chefes, que a seu ver devem ser os principais executores da mesma, para o referido Manual - trabatho de valor inegável pela clareza e objetividade com que põe ao alcance de todos os chefes a técnica de simplificação, e cuja eficácia já foi comprovada na prática, conforme esta Revista dará testemunho, publicando, a seguir, os resultados do primeiro "Programa de Simplificação do Trabalho a Cargo dos Chefes", levado a efeito pela Divisão de Organização do I.A.P.I. 